\title{
Valuing Watershed Services in Mexico’s Temperate Forests
}

\author{
Gustavo Perez-Verdin ${ }^{1 *}$, Jose Navar-Chaidez ${ }^{1}$, Yeon-Su Kim² ${ }^{2}$ Ramon Silva-Flores $^{3}$ \\ ${ }^{1}$ Instituto Politécnico Nacional, CIIDIR, Sigma 119, Durango, Mexico \\ ${ }^{2}$ Northern Arizona University, School of Forestry, Flagstaff, USA \\ ${ }^{3}$ Forest Consultant, Durango, Mexico \\ E-mail: "guperezv@ipn.mx
}

Received August 11, 2011; revised September 14, 2011; accepted October 15, 2011

\begin{abstract}
Water resources are highly valuable in arid, semiarid, or high-altitude areas where the sources are restricted to groundwater or flash floods occurred in short periods of time. In this paper, we present a case study where water is economically valued through nonmarket valuation techniques. A follow-up review of similarlyconducted case studies in Mexico was carried out to evaluate the potential relationships that elevation, moisture index, and human development index have over the economic value of water. The main factors influencing the value of water in our case study were income, education, age, and family size. Bivariate correlations of the case studies in the country suggest that there is no a significant relationship between water value and elevation, although there is some relationship between water value, moisture index, and the human development index. Dryer areas and more developed communities tend to pay more for an improvement in current water resources conditions. These results can help decision-makers to consider regional policies aimed to improve water management conditions in semiarid and less-developed communities in Mexico.
\end{abstract}

Keywords: Durango, Contingent Valuation, Non-Market Valuation, Moisture Index, Water Scarcity

\section{Introduction}

Water scarcity tends to be critical in high-altitude and semiarid environments [1]. The available water in semiarid areas is restricted to groundwater, in the form of wells or springs, or flash floods during short periods of time. If natural availability of available water falls below $1000 \mathrm{~m}^{3}$ per capita per year, then critical water scarcity is observed, and constraints to economic development emerge [2]. To spatially represent water availability, [3] modified a moisture measure that Thornthwaite and Mather created in 1955 to identify water scarcity regions. This modified, dimensionless climatic moisture index is a measure of the balance between annual precipitation and potential evapotranspiration and ranges from +1 to -1 with wet climates showing positive values and dry climates negative values. The majority of Mexico's land area, dominated by mountain scenarios, is classified as semiarid with some areas, particularly in southern Mexico, as humid or sub-humid areas [3].

High-elevation areas fulfill important ecological and economic functions for surrounding lowlands. Highlands, (e.g., areas situated 1000 meters above sea level, [4]), provide a range of environmental services to lowlands including irrigation, drinking water, biodiversity, and carbon sequestration, among others, but little is used right there in the highlands [5]. The use of these environmental services is even more constrained if an area is found in low water availability environments. As indicated by Messerli et al., "“.. the world's most significant water towers [mountains] are found in arid and semiarid environments." [6, page 30]. This is particularly true in arid or semiarid areas where the contributions of mountains to total discharge accounts for more than $50 \%$, while in humid areas this contribution is less than $50 \%$ [4].

Runoff in mountain-based areas is characterized by an extraordinary heterogeneity of topography, vegetation and soils, spatially and temporally differentiated levels of precipitation, as well as annual climate variability [6]. These characteristics make somewhat difficult for highland residents to retain and use water for domestic, industrial purposes. In many cases, these residents have to pay to bring back products, such as potable water, food, and electricity, when ironically the main input is generated where they live. The economic theory suggests that when more resource inputs are required to supply water to end users, its price rises. It is therefore necessary to 
estimate the value of water considering the source and management actions to ensure its supply to end users.

Some studies in Mexico have analyzed the demand of water by estimating the willingness to pay for water resources in various cities across the country [7-9]. In most of them, economic factors such as income have been some of the major factors determining the willingness to pay for water. Overall, wealthy people tend to state higher amounts of money than poor [8-10]. However, no studies have been conducted to analyze the effects of climatic and altitudinal variations in determining the value of water. Has precipitation, elevation, or evaporation some effect on the value of water? Answers to this type of questions have not been addressed, because the majority of studies put aside the location effect and focuses on one-time, one-point estimations. Addressing the temporal scale is currently beyond this study as it would require panel data that for now are not attainable. Instead, the study focuses on analyzing the location effect by looking at different water value estimates conducted in various parts of the country.

In this study, we present a case study where residents of a relatively small city located up in the Sierra Madre in central Durango use water from a small watershed for domestic purposes. We estimated individual and total benefits for preserving the forest resources in the watershed and identified the main factors affecting willingness to pay (WTP). We compared the WTP results of this case study with other works developed in Mexico based on three exogenous variables: elevation, moisture index, and the Human Development Index (HDI). Specifically, the study attempted to 1) estimate the value of water or the willingness to pay for preserving forest ecosystems in El Salto, Durango, and 2) analyze the effects of altitude and moisture variations on the willingness to pay for water resources. In the first objective, we conducted face-toface interviews to a sample of El Salto residents and applied the contingent valuation technique to determine the economic value that El Salto residents would pay for preserving forest resources and protect the watershed from where they receive the water. In the second objective, we carried out a review on water value from studies conducted in Mexico. We evaluated the potential relationship between expected social benefits and the physical, economic conditions of the communities, particularly the value of water and its relationship with altitude, moisture index, and quality of life. This study is the first to show the location effect on the value of water considering various moisture, altitude, precipitation, and evaporation conditions, as well as quality of life in Mexico.

\section{Study Area}

The case study was conducted in the community of El
Salto, Pueblo Nuevo located about $100 \mathrm{~km}$ west from Durango city, the capital and main city of the state of Durango, Mexico (Figure 1). The El Salto is the biggest city of the Pueblo Nuevo County and sits at 2540 meters above sea level. The area is dominated mostly by pineoak forests with small holdings where landowners farm the land. The area receives about $800 \mathrm{~mm}$ of annual precipitation and has an annual mean temperature of $11^{\circ} \mathrm{C}$. In 2000 , the city constructed a dam not only to ensure the supply of water in critical years, but also to prevent the community from potential floods and retain soil sediments. The dam (later known as The Rosilla lake) has a storing capacity of 1.3 million $\mathrm{m}^{3}\left(\mathrm{Mm}^{3}\right)$ and was constructed at the lowest point of the 944-ha catchment area [11]. Prior to its distribution to approximately 21,000 users, water is filtered through a chlorine-based system and transported via plastic tubes. The La Rosilla Lake is the only water reservoir in the surrounding area and local residents consider it as a very important source of water. A much smaller dam was constructed downstream ( $\mathrm{La}$ Rosilla dam I) to help water managers and local residents to deal with the issues of flood protection and water supply.

While historical records suggest that the lake has never dried out (Figure 2), the annual available water per person has been estimated at $109 \mathrm{~m}^{3} /$ person [11], a share that is well below the $1000 \mathrm{~m}^{3} /$ person/year threshold marked by several organizations, including the National Council of Water (CNA 2008). Current water consumption in the El Salto community is estimated at $1.5 \mathrm{Mm}^{3}$ per year ${ }^{1}$ [11], which gives a $0.2 \mathrm{Mm}^{3}$ per year water deficit. To meet total demand, local residents have to purchase bottled water or haul it from distant springs.

Other issues have jeopardized the supply of water to local residents. The watershed has been excluded from timber harvesting and protected against fires and diseases. These protection and management practices are shared largely by the landowners and partly by the federal government. Ejidatarios, or landowners where the dam was constructed, demand a fee to cover their expenses incurred in the preservation of the forest ecosystem, while voluntarily giving up timber production and reducing grazing. Recently, ejidatarios attempted to modify their forest management plan and initiate harvest operations within the watershed if their petition of economical compensation is denied [12]. According to forest managers, negating their petition could lead to water flow and soil alterations and eventually reduction of the useful life of the dam. A final issue is related to the storing capacity of

\footnotetext{
${ }^{1}$ The water balance model estimations are based on year-to-year information. Thus, monthly variations can be expected throughout the year. We sought monthly evaluations, but no information was available at this time.
} 


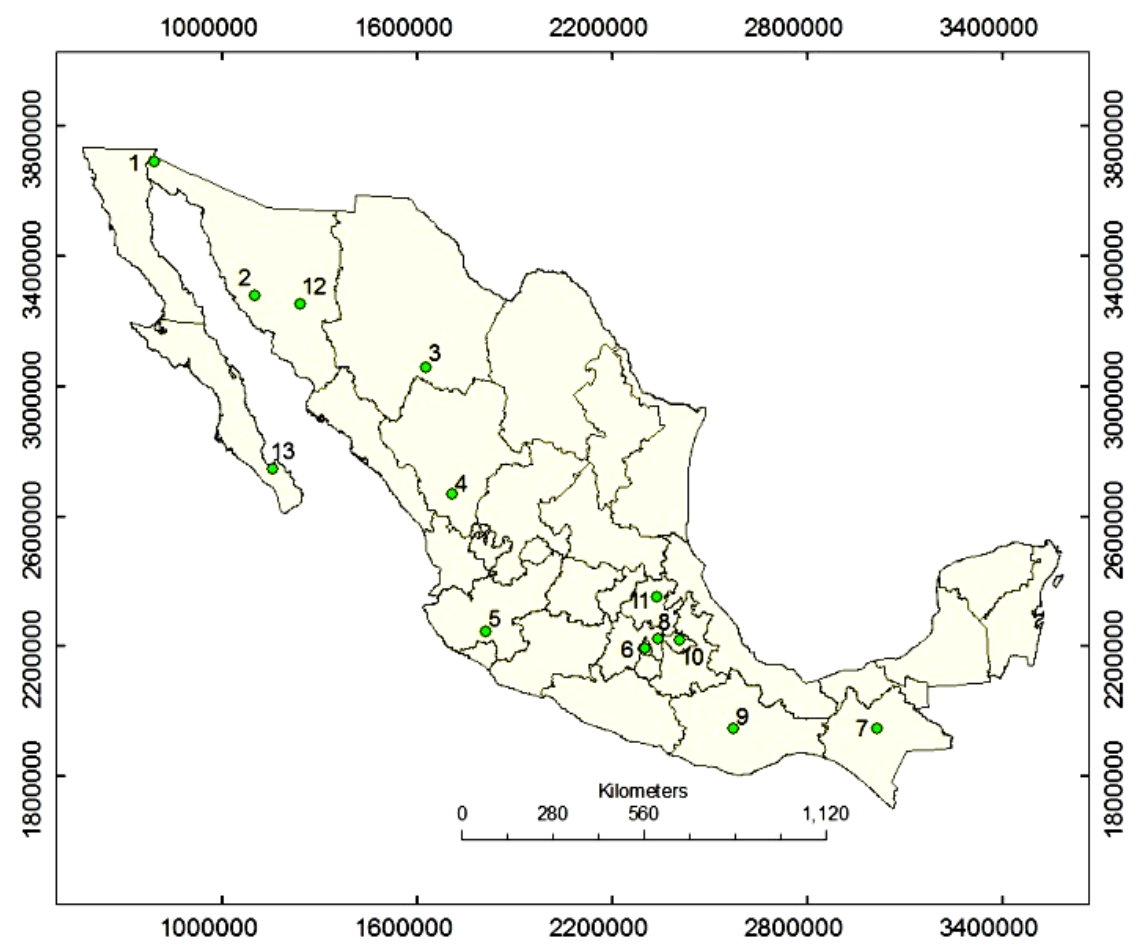

Figure 1. Location of the El Salto community, Durango. The figure also shows the cities with WTP studies on water resources in Mexico (see Table 3 for corresponding names).

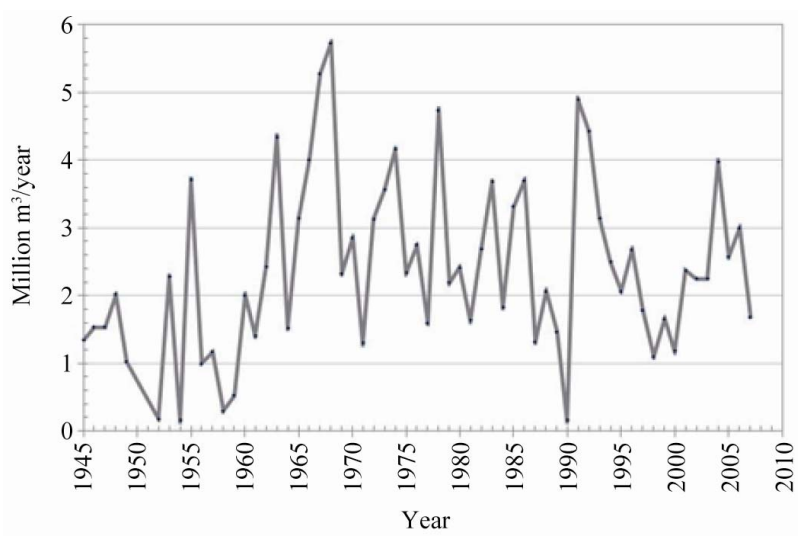

Figure 2. Historical water balance for the La Rosilla lake, near El Salto, Dgo., Mexico. The water balance means the difference between inputs (precipitation) and outputs (evaporation, infiltration, runoff, etc.). Source: [2] and authors' research.

the lake, which is not enough to cover increased water demand. This concern has been discussed in public meetings and ideas such as elevating the dam have been considered [12]. So far, no studies or projects to address this concern have been conducted.

\section{Estimating the Value of Water Benefits}

Research has focused on how to estimate an economic value to environmental services to redirect policies oriented for sustainable water management. The intention is to help landowners to reduce the impact of externalities by giving monetary resources and implement best management practices to regulate the quality/quantity of water $[5,13]$. The need of economic valuation of water benefits stems from their quasi-public and non-rivalry nature, the presence of externalities, and scales of production $[14,15]$. If economic valuation is absent, water benefits will not be provided at optimal levels. The nonexclusive, non-rivalry nature implies that it is difficult, if not impossible, to exclude an individual from using water benefits (e.g. aquatic habitats, recreation), and several individuals can use the services simultaneously without diminishing each other's use values. The presence of externalities means that the economic profit of users of these services will not be deviated to compensate providers. And regarding the scale of production, these services are characterized by economies of scale in production; the larger the watershed, the lower the marginal costs [16].

The value of water benefits was estimated using the Contingent Valuation (CV) approach. CV is a nonmarket valuation technique used to estimate societal values for public goods [17]. The CV approach employs surveybased techniques to directly elicit households' preferences and build a contingent market through which re- 
spondents may state their willingness to pay/accept for a specified provision change in a particular service [18]. The CV approach first involves describing the current situation of a non-market service, how it can be improved, and then asking respondents whether or not they would pay/accept for an improvement/compensation of the specific good [19]. It is called contingent valuation, because people are asked to state their willingness to pay/accept, contingent on a specific hypothetical scenario and description of the environmental good [20]. The willingness-to-pay results can then be used by decision makers to weigh policy options.

The CV method has been extensively applied to estimate water value in many parts of the world. In Mexico, only a few cases can be outlined for altitudinal and climate differences. Among these are the Gutierrez-Villalpando work in the city of San Cristobal de las Casas, Chiapas, located in southern Mexico, in which they evaluated willingness to pay for an improvement of the riparian ecosystem that supplies water to the city [21]. Also, López-Paniagua et al. used CV to assess the feasibility of the development of an environmental market for water in the upper watershed of Rio Tapalpa, Jalisco. This area is located in the Neovolcanic Axis and sits at $1950 \mathrm{~m}$ above sea level [7]. A more recent study was finished in 2008 in the city of Ciudad Obregon, Son, near to the Mexico-US border where they evaluated the value of instream flows in the Yaqui river [22].

\subsection{Sample Size and Characteristics of Respondents}

To estimate the social benefit of an improvement of current conditions of the Rosilla watershed, we surveyed a sample of local residents of El Salto city. A sample size was calculated using the standard equation for variables subjected to proportions [23]. The sample size was estimated at 242 households, with an error proportion of \pm $6 \%$ and $95 \%$ of confidence. Each household was randomly selected using a city map and in each household a person, older than 18, was invited to participate in a faceto-face interview ${ }^{2}$. The questionnaire included three types of general questions: level of knowledge of the quality of the service, willingness to pay (WTP) for a hypothetical scenario, and socioeconomic background of respondents. An open-ended question format was used to elicit local residents' willingness to pay. The open-ended question was designed in such a way that each respondent openly stated their closest preference towards an improvement

\footnotetext{
${ }^{2}$ With random sampling, each household in the city had the same probability of being selected. This characteristic avoided issues related to selection bias and enabled use of statistical theory to make valid inferences from the sample to the targeted population [26].
}

of the watershed conditions or not. The reason to use open-ended question (as opposed to referendum format) was because it allows zero value responses which oftentimes are fairly robust to alternative assumptions made about respondent beliefs [20]. In addition, while there is some evidence that referendum format may minimize hypothetical bias, it is not clear that this format alone can completely eliminate potential bias [24]. Carson and Groves suggest that the choice between open-ended or referendum format, or between bias and variance, comes down to the researcher's objectives [20].

After providing with information of the watershed and hypothetical scenarios of action and no action in the area, it followed the WTP question, which was stated as follows: "It is important to protect the forests in the Rosilla watershed so they can ensure water supply to El Salto residents. Would you be willing to pay a monthly extra fee to keep preserving the area and secure water supply? Yes/No". Then, respondents provided their WTP amount of money.

The information was collected in 2007 and some of the socioeconomic characteristics of respondents are presented in Table 1. The sample closely resembles the characteristics of the total population of the city. Differences were observed in age, sex, occupation, and marital status. Part of these differences can be explained to survey procedures including the time when the interviews were conducted. The questionnaires were applied during work hours and responded by the person most commonly found in the household at such time. In the majority of cases $(62 \%)$, the respondents were women, whose characteristics increased age and marital status data, but decreased percentage of occupation ${ }^{3}$.

Table 1. Characteristics of sampled and total population of El Salto residents.

\begin{tabular}{ccc}
\hline Variable & $\begin{array}{c}\text { Sample } \\
(n=242)\end{array}$ & $\begin{array}{c}\text { El Salto city } \\
(N=21,793)^{\mathrm{a}}\end{array}$ \\
\hline Percentage of women & 62.0 & 51.4 \\
Average age (years) & 41.6 & 26.6 \\
Household family size (\# of people) & 5.0 & 4.6 \\
Average household income (MX\$/month) & 2988 & 2937 \\
Gini coefficient & 0.34 & $0.482^{\mathrm{b}}$ \\
Percentage with high school education & 21.0 & 16.7 \\
Percentage of occupation & 51.6 & 68.0 \\
Percentage of married people & 73.0 & 62.9 \\
\hline
\end{tabular}

${ }^{a}$ Source: Conteo de Población y Vivienda 2005 [25]. ${ }^{b}$ Corresponds to the 2008 national average.

${ }^{3}$ Occupation in this study was considered as the type of employment provided by a public institution or private entrepreneur in which a worker continuously receives a wage. 


\subsection{Model Specification to Estimate Water Economic Value}

We used the ordinary least squares method to fit the parameters included in the model. We first analyzed whether predictors met the restrictions imposed to linear regression models and found that some variables required logarithm transformations. We then decided to use a loglinear model to mitigate problems associated with heterocedasticity, skewness, and high variability of predictors [26]. The log functional form with $k+1$ predictors was expressed as:

$$
\log (w t p)=\beta_{0}+\beta_{k} x_{k}
$$

where $x_{k}$ are the predictors, $\beta_{0}$ is the intercept, and $\beta_{k}$ is the parameter associated with $x_{k}$. The mean $W \bar{T} P$ estimate was given by:

$$
W \bar{T} P=\left[e\left(\sum_{i=1}^{m} W \hat{T}_{i}\right) / m\right]
$$

where $W \hat{T P}$ is the predicted WTP for person $i$ and $m$ is the number of respondents. Confidence intervals (CI) for $W \overline{T P}$ at a $95 \%$ confidence level can be calculated using the standard error and applying the typical formula in which $\mathrm{CI}=W \bar{T} P+1.96 \cdot s e_{W \overline{T P}}$. Also, for logarithm-transformed predictors, the percentage change $(\Delta)$ (i.e., semielasticity) of WTP evaluated at the mean of predictor $i$ was calculated as $\% \hat{\Delta}_{\text {WTP }}=\beta_{k}$. For non-transformed predictors, we used the following expression [26]:

$$
\% \hat{\Delta}_{\text {WTP }}=100\left[\exp \left(\hat{\beta}_{k} \Delta x_{k}\right)-1\right]
$$

Equations (1) and (2) were used to estimate the amount of money that person $i$ would be willing to pay for improving actual watershed conditions and identify the main variables influencing the choice. Among the factors included in the analysis were income, age, family size, and education. No prior expectations of signs were assumed, except for income, in which literature suggests that the probability and amount of WTP increase as income also increases $[8,9,22]$.

In order to know not only the expected value of the WTP but also the distribution of the benefits from this potential change, we estimated a probability distribution function of predicted WTP. The fitted probability distribution function also allowed us to identify differences between the mean and median due to sample distribution and eventually to choose the best statistics and draw more general conclusions. If non-normal or asymmetric probability distribution functions are expected, the choice between the mean and median has large implications for the desirability of undertaking the provision of the water service and the method of financing it [18]. In this case, the mean WTP was calculated as the area under the probability distribution function and the median was the amount of money in which the probability of accepting such an improvement is 0.5 . To do this, we tested various probability functions for predicted WTP and selected the best using the Kolmogorov-Smirnov test [26]. Following Kristrom, the equation that represents the mean for predicted WTP is given by [27]

$$
W \tilde{T P}=\int_{0}^{\infty} 1-F_{W T P}(A) \partial A-\int_{-\infty}^{0} F_{W T P}(A) \partial A
$$

where $W \tilde{T} P$ is the mean of the predicted WTP, $F_{W T P}$ is a continuous, non-decreasing function (such as the logit or log-logistic model) and $A$ the amount to pay. The median WTP $\left(M_{\text {WTि }}\right)$ is obtained by solving for $A^{+}$in the following equation:

$$
M_{\text {WĨP }}=F_{W T P}\left(A^{+}\right)=0.5
$$

\subsection{Review of WTP Studies in Mexico}

In recent years, several studies have been conducted in Mexico to estimate the value of water using non-market valuation techniques. We searched various information sources and found that some studies, which covered from the northern state of Sonora to the southern state of Chiapas (Figure 1), used the $\mathrm{CV}$ method to estimate social benefits from water resources. The first information source involved a literature search from all available databases (e.g. Web of Science) and the web for nonmarket valuation studies. A brief review of the abstracts and introductions served to select articles directly related to water values and CV. Second, all articles relating to the topic were thoroughly reviewed to identify ecological, social and economic factors that needed to be considered. We also reviewed the citations of published articles to find any unpublished data or papers. The factors identified were coded, georeferenced, and compiled in a database.

The reason to review WTP studies across the country was to analyze the potential relationship between WTP and the physical, economic conditions of the community. These included the location (altitude), natural availability of water, and quality of life. To the best of our knowledge, no studies have been conducted to analyze these types of relationships. Attempting to compare WTP studies was cumbersome due to a diversity of objectives: some estimate the value of water for recreation amenities, others for ecosystem preservation and environmental attributes, and others for improving residential services. Some even were fussy in terms of defining what specific public service was being evaluated. We discarded those studies with multiple objectives and overall WTP estimations, and retained those where water value was inde- 
pendently, explicitly estimated. We recognized that comparison across water-related valuation studies may not be appropriate if WTPs from these studies were payments for different purposes (e.g., improving residential service or environmental attributes). But, our goal was to consider the diversity of water benefits and compare use and non-use values [28].

In reviewing these works, we tried to find out the value of water benefits based on the main priorities of users and non-market valuation techniques. We focused on the characteristics of local (physical and economic) conditions and the stated amount of money residents gave to water for personal or environmental uses. The physical and socioeconomic conditions were grouped into three variables: elevation, moisture index, and a Human Development Index (HDI). Elevation is measured in meters above sea level while the moisture index is based on both monthly precipitation $\left(P_{T}\right)$ and evaporation $\left(E_{V}\right)$ data [3]. The expression used to calculate the moisture index $(M I)$ was:

$$
M I=1-E_{v} / P_{T}
$$

The closer the MI gets to +1 , the wetter the area. Data of elevation and moisture index were obtained from a spatially-published database by the National Institute of Geography.

The HDI is a common measure used to rank societies as a function of life expectancy, education, and per capita gross domestic product $[29,30]$. Even though the HDI measure has been criticized because it fails to address ecological factors, it has been used as a standard measure to classify economies based on their individual performance [31]. The HDI index goes from 0 to 1 , where higher values mean higher economic development. The HDI data were taken from the National Council of Population [32].

\section{Results}

\subsection{Willingness to Pay}

Survey results indicate that the vast majority of respondents $(90 \%$ of the sample) were willing to pay for preserving watershed conditions. The amounts ranged from MEX\$ 5 to MEX\$ 200 per month. The main variables affecting the probability of paying for an improvement were education, age, family size, water bill, and income (Table 2). Older and richer people were more likely to pay more for an improvement of the watershed whereas the amount decreased as respondents had bigger families. Though not significant, there was a slight, positive correlation between monthly income and water bill, which suggests in part that people who are now paying more are willing to pay even more, that is, the WTP amount increases as the water bill increases too. Contrary to other studies [8,9], the WTP amount decreased as people are more educated. A possible explanation of this finding is that $70 \%$ of the sample reported secondary education as their maximum level of education. In this community, many people drop off school to get a job to contribute to their family's economy. Being this a rural community, many of these jobs are directly or indirectly related to the forest. We believe that high levels of perception of watershed protection to ensure water supply in less educated people are due to the living experiences in forestrelated jobs. During the survey, we asked respondents about the importance of forests in providing the water they consume; the answer, on a scale from 1 (not important) to 10 (very important), was $4 \%$ higher in those who had low-levels of education than those with higher levels.

To have a better perspective of the model, we estimated the elasticity of predictors. These coefficients are

Table 2. Ordinary least squares estimates of the log-linear functional form for El Salto residents.

\begin{tabular}{|c|c|c|c|c|}
\hline Variable & Mean & Coefficient & $t$-ratio & Elasticity $(\%)$ \\
\hline Constant & & -0.905 & -0.856 & \\
\hline Age (\# of years) & 41.01 & 0.013 & 2.52 & 1.34 \\
\hline Education ( 1 primary; 2 secondary: 3 high school; 4 college; 5 posgrade) & 2.48 & -0.112 & -2.41 & -10.62 \\
\hline Water bill (MX\$) & 33.18 & 0.008 & 2.92 & 0.803 \\
\hline Log Income (MX\$) & 7.85 & 0.455 & 3.41 & 0.455 \\
\hline Number of observations & & 242 & & \\
\hline
\end{tabular}


interpreted as percentages of change of the independent variable on WTP (Equation (3)). For example, a one percent increase in family size, ceteris paribus, the WTP amount decreased by $6.8 \%$. Also, one percent increase in the age of respondents also increased the amount by $1.3 \%$. Increases or decreases in the water bill have a marginal impact on WTP. The income effect is also significant but marginal; after taking off the logarithm effect, a unit increase in the mean income, holding all else constant, increases the WTP amount by $0.45 \%$.

Mean WTP estimated through Equation (2) resulted in MEX\$ 19.24 with a confidence interval of MEX\$ 17.86 to 20.61 per month. Other statistics showed that predicted WTP values had some asymmetric distribution (skewness $=3.7$ and kurtosis $=21.5$ ), which strengthened our idea of taking a closer look at the measures of central tendency. To get the best probability distribution function of predicted WTP, we simulated various probability functions and obtained the best fit using the Kolmogorov-Smirnov test. Results indicate that the best fit was obtained through the log-logistic model. Using Equations (4) and (5), mean and median WTP for predicted WTP were MEX\$ 19.20 and 17.11 per month, respectively (Figure 3). The mean WTP is the area under the distribution function whereas the median WTP represents the probability that half of the sample accept an improvement, i.e. when the probability of saying yes is $50 \%$. Note that the mean WTP is practically the same in both procedures.

Differences between the mean and median are due to an asymmetric distribution of benefits of the water service improvement [33]. In this case, a portion of the sample did not see substantial benefits with the policy change, but the rest is willing to pay considerable amounts to keep preserving the ecosystem watershed. There have been various studies debating about which measure should be used in contingent valuation studies [34-37]. The mean is very sensitive to the right tail of the distribution; that is, to responses of higher bidders [35]. Hanemann suggests that if the mean is to be used, a probability distribution function estimation such as the one used here, is to be applied [36]. In addition, the mean WTP is recommendable when it is necessary to estimate a total value and when benefits are being compared with opportunity costs [33]. Due to these reasons, the WTP for this study was based on the mean value (Figure 3). The total benefits for the whole city, considering 5689 occupied households [25], was MEX\$ 1.31 million/year (US\$ 100,826/year) with a confidence interval of MEX\$ 1.22 and MEX\$ 1.41 million/year.

\subsection{The Value of Water in Other Environments}

We found some differences between our WTP results and those obtained elsewhere in Mexico. The overall WTP mean was MEX \$73 while El Salto gave MEX \$19.

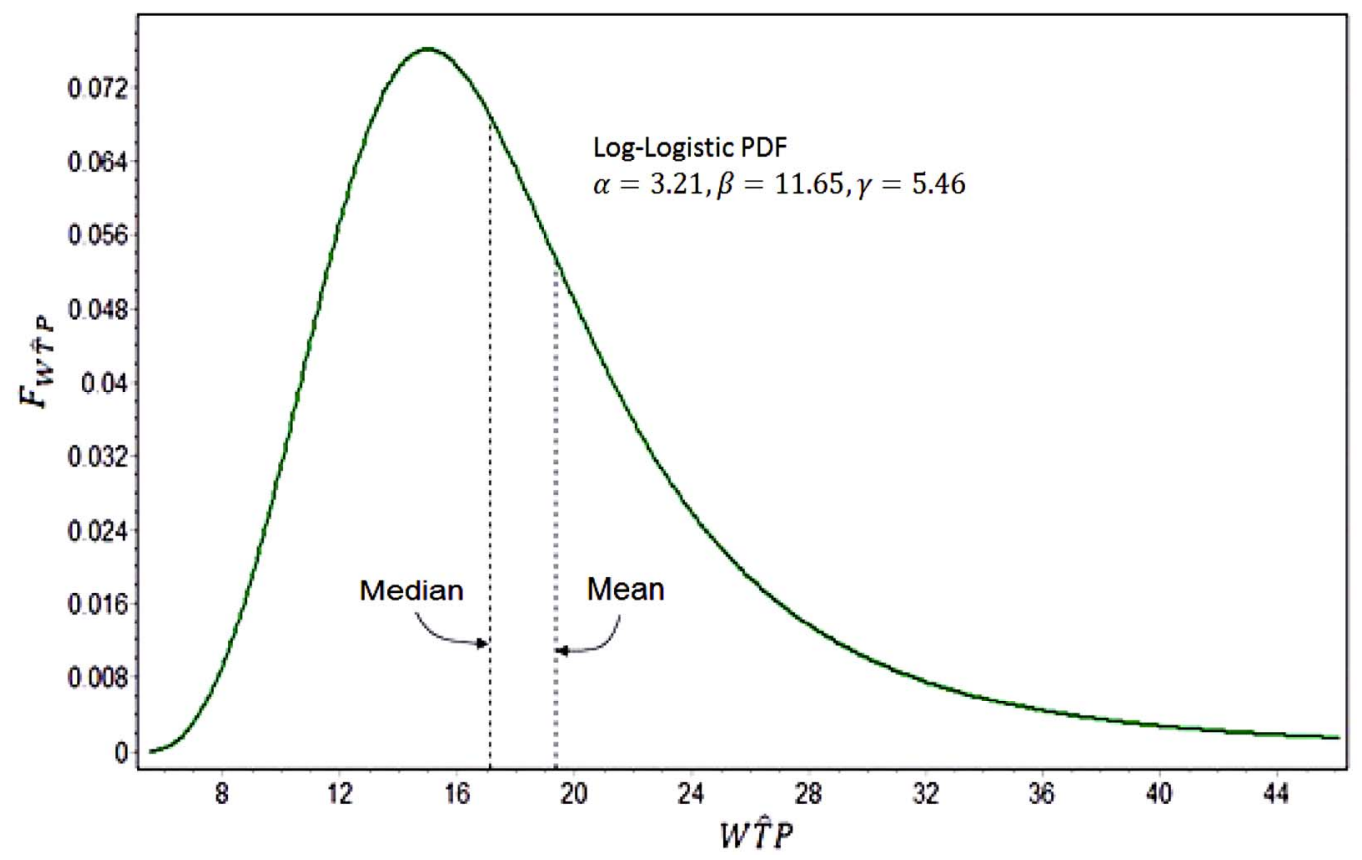

Figure 3. Log-logistic probability distribution function of predicted WTP for El Salto Residents. The Kolmogorov-Smirnov statistics was 0.036 with $p=\mathbf{0 . 9 5}$, thus the null hypothesis of data coming from the specified distribution cannot be rejected. Also shown the values of the three parameters estimated in the fitting. 
Mean elevation, MI, and HDI were $1498 \mathrm{~m}, 0.781$, and 0.117 , whereas for El Salto were $2540 \mathrm{~m}, 0.774$, and 0.25 , respectively (Table 3 ). To evaluate a potential relationship between water value and each of the factors, and considering the low number of case studies, we performed simple bivariate correlations (Figure 4). Overall, no significant association was found between WTP and elevation $(r=-0.27, p=0.37)$. The lack of significant correlation between elevation and WTP can be explained in part by the great diversity of topographic conditions where large cities, such as Mexico City, located in high altitude areas, have high levels of demand, and probably are willing to pay large amounts of money for the water they use. Mexico City residents for example consume water at a rate of 64 cubic meters per second $\left(\mathrm{m}^{3} / \mathrm{s}\right)$ while the supply has been estimated at $54 \mathrm{~m}^{3} / \mathrm{s}$ [8]. Their WTP estimates suggest a high latent demand and value perception over policies aimed to improve water service ${ }^{4}$.

The moisture index (MI), a measure of dryness, had a significant inverse correlation with WTP $(r=-0.64, p=$ 0.02 ). Cities located in dryer environments tend to pay higher values for water services than wetter cities. This finding coincides with that of the economic theory in which individuals pay higher amounts of money for scarce resources. In contrast, the HDI, a measure of the quality of life, has a direct relationship with WTP $(r=$ $0.64, p=0.02$ ). Cities with better quality of life standards tend to give higher values than less-developed cities. Figure 4 shows individual relationships between WTP and each factor. The exploratory results of these types of relationships can help resource managers to consider regional-aimed policies to improve water management conditions in arid and less-developed communities in Mexico.

\section{Conclusions}

This research presented a case study where water is economically valued using non-market valuation methods. Residents of a rural community in Durango, Mexico participated in face-to-face interviews to help estimating total social benefits about the preservation of the forest ecosystem from which they obtain their potable water. Contingent valuation was used to estimate the amount of money residents were willing to pay for preserving the forests of the Rosilla watershed. A log-linear model and probability density function were used to estimate mean WTP. Results showed that the majority of respondents ( $90 \%$ of the sample) are willing to pay for preserving watershed conditions. Mean WTP estimated using Equation (2) was estimated at MEX\$ 19.2/month (US\$ 1.5/

\footnotetext{
${ }^{4}$ Water in Mexico City is pumped from a $1600-\mathrm{m}$ to $2200-\mathrm{m}$ elevation differential to reach users [2].
}

month) with a confidence interval of MEX $\$ 17.86$ to 20.61. The main factors influencing acceptance of the payment were income, education, age, family size, and water bill. The total benefit for the entire population was estimated at MEX\$ 1.31 million/year (US\$ 100,826/ year).

Based on the analysis of WTP studies developed so far in Mexico, there was no significant relationship between elevation and WTP. The analysis was based on several cities distributed in an altitudinal gradient from 10 to $2540 \mathrm{~m}$ above sea level including Mexico City, the world's third largest metropolitan area, located at $2240 \mathrm{~m}$. According to the national water agency, a moderate proportion of high-altitude areas in Mexico shows similar deficits of water supply [2] and their residents, as evidenced by the Mexico City case, are probably willing to pay large amounts of money to compensate for these deficits. Large WTP amounts were also registered in lowaltitude cities such as La Paz and Alamos. Based on our analysis, the topographic heterogeneity of the country, where almost $55 \%$ of the total population lives above the 1000-m elevation line [25], made elevation not important to determine the value of water.

Results provided evidence that the moisture and human development indexes are statistically correlated with WTP. Dryer areas and more developed communities tend to pay more for improved water resources. The moisture index finding coincides with basic economic theory which suggests that scarce resources are more appreciated. Regarding HDI finding, there is an increasing debate whether communities with better quality of life are more likely to contribute to ecosystem preservation. Some argue that economic growth and conservation are incompatible goals, but others say that wealthier communities have the luxury of investing more heavily in efforts to ecosystem conservation [44,45]. To have a more comprehensive conclusion it is necessary more studies that analyze the relationship between WTP and human development index or other type of economic growth metrics.

The analysis presented in this explorative study motivates us to continue investigating the relationship between water value and exogenous variables based on non-market valuation methods in Mexico. Adding more studies should reinforce the decision-making process of correctly allocating financial resources for different purposes such as improving current management and distribution systems, protecting high-value watersheds, or providing water to low-income families.

\section{Acknowledgements}

We thank CONACYT and the Instituto Politecnico Na- 
Table 3. Cities with WTP estimations for water in Mexico.

\begin{tabular}{|c|c|c|c|c|c|c|}
\hline Study site & $\begin{array}{c}\text { Water } \\
\text { attribute }^{\mathrm{a}}\end{array}$ & $\begin{array}{c}\text { Elevation } \\
\text { (meters) }\end{array}$ & $\begin{array}{l}\text { Moisture } \\
\text { index }^{\mathrm{b}}\end{array}$ & $\begin{array}{l}\text { Human Development } \\
\text { Index }^{\mathrm{c}}\end{array}$ & $\begin{array}{l}\text { Adjusted WTP } \\
\text { (US\$/month) }^{\mathrm{d}}\end{array}$ & $\begin{array}{c}\text { Source of WTP } \\
\text { estimations }\end{array}$ \\
\hline 1. Ciudad Obregon, SON & E, R & 35 & 0.146 & 0.834 & 6.12 & [22] \\
\hline 2. San Luis Rio Colorado, SON & $\mathrm{E}$ & 40 & 0.055 & 0.826 & 6.39 & [38] \\
\hline 3. Parral, CHIH & $\mathrm{R}$ & 1,620 & 0.089 & 0.810 & $8.915^{\mathrm{e}}$ & [9] \\
\hline 4. El Salto, DGO & $\mathrm{E}$ & 2,540 & 0.250 & 0.733 & 2.08 & This study \\
\hline 5. Tapalpa, JAL & $\mathrm{E}$ & 1,950 & 0.135 & 0.732 & $9.10^{\mathrm{f}}$ & {$[7]$} \\
\hline 6. Mexico City, DF & $\mathrm{R}$ & 2,240 & 0.064 & 0.849 & $15.81^{\mathrm{g}}$ & {$[8]$} \\
\hline 7. San Cristobal de las Casas, CHIS & $\mathrm{R}, \mathrm{E}$ & 2,120 & 0.306 & 0.752 & 1.82 & {$[21]$} \\
\hline 8. Tepetlaoxtoc, EDOMEX & $\mathrm{E}$ & 2300 & 0.088 & 0.751 & 4.98 & [39] \\
\hline 9. Oaxaca, OAX & $\mathrm{E}$ & 1555 & 0.105 & 0.834 & 3.11 & {$[40]$} \\
\hline 10. Tlaxco, TLAX & $\mathrm{E}$ & 2588 & 0.074 & 0.743 & 1.83 & [41] \\
\hline 11. Metztitlan, HGO & $\mathrm{E}$ & 2080 & 0.091 & 0.686 & 0.45 & {$[42]$} \\
\hline 13. La Paz, BCS & $\mathrm{R}$ & 10 & 0.048 & 0.817 & 10.15 & [10] \\
\hline
\end{tabular}

${ }^{\mathrm{a}}$ Water use: E: Environmental/protection; R: Residential service. ${ }^{\mathrm{b}}$ Based on average precipitation and evaporation data. ${ }^{\mathrm{c}}$ Based on county-level estimations by CONAPO (National Council of Population). ${ }^{\mathrm{d}}$ Februrary-2010 price levels (US\$ $1=$ MEX\$ 13 , average annual inflation rate $=4.4 \%$ ). ${ }^{\mathrm{e}}$ Open-ended question. No certainty correction ${ }^{\mathrm{f}}$ Includes domestic sector only. ${ }^{\mathrm{g}}$ Average across five income groups and improvement scheme.

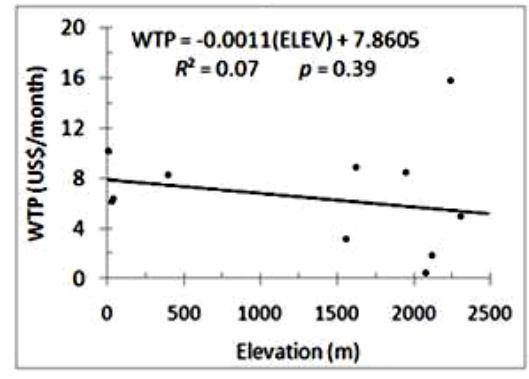

(a)

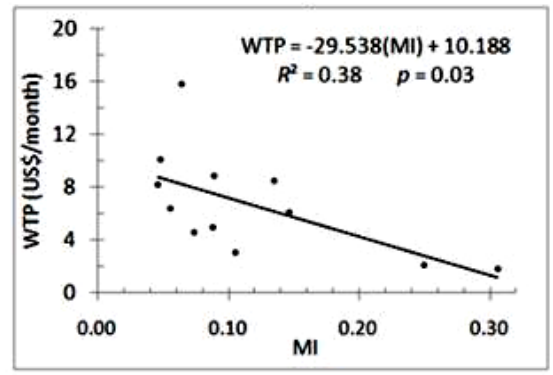

(b)

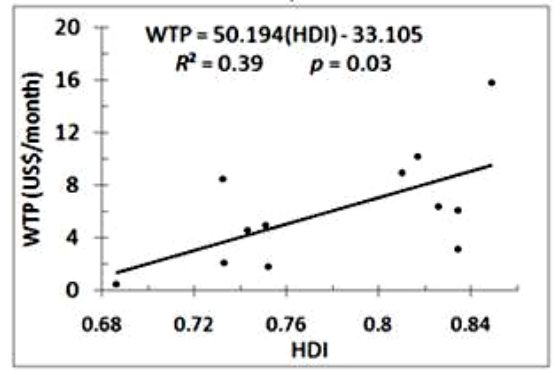

(c)

Figure 4. Relationships between WTP and (a) elevation, (b) moisture index, and (c) human development index.

cional for partially funding this study. The ejido La Victoria and CNA provided valuable forest inventory and climatic data, respectively. Our thanks also go to El Salto residents for participating in the interviews. Part of this study was presented at the 2010 ACES conference in Phoenix, AZ. We thank attendees for constructive inputs.

\section{References}

[1] K. Froehlich and Y. Yurtserver, "Isotope Techniques for Water Resources in Arid and Semiarid Regions. Application of Tracers in Arid Zone Hydrology," Proceedings of the Vienna Symposium, August 1994, Vol. 232, 1995, pp. 3-12.

[2] CNA (Comisión Nacional del Agua), "Estadísticas del Agua en México. Edición 2008. SEMARNAT," Talleres Gráficos, México, 2008

[3] C. J. Willmott and J. J. Feddema, "A More Rational Climatic Moisture Index," The Professional Geographer, Vol. 44, No. 1, 1992, pp. 84-88. doi:10.1111/j.0033-0124.1992.00084.x

[4] D. Vivirolli, R. Weingartner and B. Messerli, "Assessing the Hydrological Significance of the World's Mountains," Mountain Research and Development, Vol. 23, No. 1, 2003, pp. 32-40.

[5] S. Pagiola, J. Bishop and N. Landell-Mills, "La Venta de Servicios Ambientales. Mecanismos Basados en el Mercado Para la Conservación y Desarrollo," INE-SEMARNAT, Mexico, 2003

[6] B. Messerli, D. Viviroli and R. Weingartner, "Mountains of the World: Vulnerable Water Towers for the 21st Century," Ambio, Vol. 33, No. 13, 2004, pp. 29-34.

[7] C. Lopez-Paniagua, M. J. González-Guillén, J. R. Valdez-Lazalde and H. M. de los Santos, "Demanda, Disponibilidad de Pago y Costo de Oportunidad Hídrica en la Cuenca Tapalpa, Jalisco," Madera y Bosques, Vol. 13, No. 1, 2007, pp. 3-23.

[8] M. G. Soto and I. J. Bateman, "Scope Sensitivity in Households' Willingness to Pay for Maintained and Improved Water Supplies in a Developing World Urban 
Area: Investigating the Influence of Baseline Supply Quality and Income Distribution upon Stated Preferences in Mexico City," Water Resources Research, Vol. 42, 2006, pp. 1-15.

[9] W. F. Vasquez, P. Mozumder, J. Hernandez-Arce and R. P. Berrens, "Willingness to Pay for Safe Drinking Water: Evidence from Parral, Mexico," Journal of Environmental Management, Vol. 90, No. 11, 2009, pp. 3391-3400. doi:10.1016/i.jenvman.2009.05.009

[10] G. Aviles-Polanco, L. Huato-Soberanis, E. Troyo-Dieguez, B. Murillo-Amador, J. L. Garcia-Hernandez and L. F. Beltran-Morales, "Valoración Económica del Servicio Hidrológico del Acuífero de La Paz, B.C.S.: Una ValoraCión Contingente del Uso de Agua Municipal," Frontera Norte, Vol. 22, No. 43, 2010, pp. 103-128.

[11] R. Silva-Flores, G. Perez-Verdin and J. J. Navar-Chaidez, "Valoración Económica de los Servicios Ambientales Hidrológicos en El Salto, P.N., Durango," Madera y Bosques, Vol. 16, No. 1, 2010, pp. 31-49.

[12] R. Silva-Flores, "Valoración Económica de Los Servicios Ambientales Hidrológicos en el Ejido La Victoria, Pueblo Nuevo, Dgo," Tesis Maestría, Instituto Politécnico Nacional, CIIDIR - DGO, Durango, 2007.

[13] C. Muñoz-Piña, A. Guevara and J. M. T. y J. Braña, "Paying for the Hydrological Services of Mexico's Forests: Analysis, Negotiations and Results," Ecological Economics, Vol. 65, No. 4, 2008, pp. 725-736. doi:10.1016/j.ecolecon.2007.07.031

[14] K. A. Brauman, C. Gretchen, T. K. Duarte and H. M. Mooney, "The Nature and Value of Ecosystem Services: An Overview Highlighting Hydrologic Services," Annual Review of Environmental and Resources, Vol. 32, 2007, pp. 67-98. doi:10.1146/annurev.energy.32.031306.102758

[15] E. Plottu and B. Plottu, "The Concept of Total Economic Value of Environment: A Reconsideration within a Hierarchical Rationality," Ecological Economics, Vol. 61, No. 1, 2007, pp. 52-61. doi:10.1016/j.ecolecon.2006.09.027

[16] S. K. Pattanayak, "Valuing Watershed Services: Concepts and Empirics from Southeast Asia," Agriculture, Ecosystems and Environment, Vol. 104, No. 1, 2004, pp. 171184. doi:10.1016/j.agee.2004.01.016

[17] F. Schlapfer, "Contingent Valuation: A New Perspective," Ecological Economics, Vol. 64, No. 4, 2008, pp. 729-740. doi:10.1016/i.ecolecon.2007.10.010

[18] R. C. Mitchell and R. T. Carson, "Using Surveys to Value Public Goods: The Contingent Valuation Method," Resources for the Future, Washington, DC, 1989.

[19] K. J. Boyle, "Contingent Valuation in Practice". In: P. A. Champ, K. J. Boyle and T. C. Brown, Eds., A Primer on Nonmarket Valuation, Kluger Academic Publishers, Norwell, 2003, pp. 111-169. doi:10.1007/978-94-007-0826-6 5

[20] R. T. Carson and T. Groves, "Incentive and Informational Properties of Preference Questions," Environmental \& Resource Economics, Vol. 37, No. 1, 2007, pp. 181-210. doi:10.1007/s10640-007-9124-5
[21] V. Gutierrez-Villalpando, "Valoración Económica del Agua Potable en la Zona Urbana de San Cristóbal de las Casas, Chiapas," Tesis de Maestría, El Colegio de la Frontera Sur, San Cristóbal de las Casas, 2006

[22] M. I. Ojeda, A. S. Mayer and B. D. Solomon, "Economic Valuation of Environmental Services Sustained by the Yaqui River Delta," Ecological Economics, Vol. 65, No. 1, 2008, pp. 155-166. doi:10.1016/j.ecolecon.2007.06.006

[23] M. L. Rea and R. A. Parker, "Designing and Conducting Survey Research: A Comprehensive Guide,” Jossey-Bass Publishers, San Francisco, 1992.

[24] J. Murphy, G. Allen and T. Stevens, "A Meta-Analysis of Hypothetical Bias in Stated Preference Valuation," Environmental and Resource Economics, Vol. 30, No. 3, 2005, pp. 313-325. doi:10.1007/s10640-004-3332-Z

[25] INEGI (Instituto Nacional de Estadística, Geografía e Informática), "II Conteo de Población y Vivienda por Localidad," Disco Compacto, México, 2005

[26] J. M. Woolridge, "Introductory Econometrics, a Modern Approach," Thomson South-Western, Mason, 2006.

[27] B. Kristrom, "Spike Models in Contingent Valuation," American Journal of Agricultural Economics, Vol. 79, No. 3, 1997, pp. 1013-1023. doi:10.2307/1244440

[28] A. M. Freeman III, "The Measurement of Environmental and Resource Values. Theory and Methods," Resources for the Future Press, Washington, DC, 2003.

[29] UNDP (United Nations Development Programme), "Indice de Desarrollo Humano Municipal en Mexico," Mexico, 2010.

http://www.undp.org.mx/desarrollohmano/eventos/images/ CuadernilloIDHMM.pdf

[30] UNDP (United Nations Development Programme), "Human Development Report. Overcoming Barriers: Human Mobility and Development," Palgrave Macmillan, New York, 2009.

[31] A. D. Sagar and A. Najam, "The Human Development Index: A Critical Review," Ecological Economics, Vol. 25, No. 3, 1998, pp. 249-264. doi:10.1016/S0921-8009(97)00168-7

[32] CONAPO (Consejo Nacional de la Población) "Indices de Desarrollo Humano 2000," Mexico, 2010. http://www.conapo.gob.mx/publicaciones/indicesoc/IDH 2000/dh Indices.pdf

[33] M. Kniivila, V. Ovaskainen and O. Saastaimoinen, "Costs and Benefits of Forest Conservation: Regional and Local Comparisons in Eastern Finland," Journal of Forest Economics, Vol. 8, No. 2, 2002, pp. 131-150. doi:10.1078/1104-6899-00008

[34] W. M. Hanemann, "Welfare Evaluations in Contingent Valuation Experiments with Discrete Responses," American Journal of Agricultural Economics, Vol. 66, No. 3, 1984, pp. 332-341. doi:10.2307/1240800

[35] W. M. Hanemann, "Valuing the Environment through Contingent Valuation," The Journal of Economic Perspectives, Vol. 8, No. 4, 1994, pp. 19-43.

doi:10.1257/jep.8.4.19 
[36] W. M. Hanemann and B. Kanninen, "The Statistical Analysis of Discrete-Response CV Data," In: I. J. Bateman and K. G. Willis, Eds., Valuing Environmental Preferences: Theory and Practice of the Contingent Valuation Method in the US, EU, and Developing Countries, Oxford University Press, New York, 1999, pp. 302-441.

[37] E. Camacho-Cuena, A. Garcia-Gallego, N. Georgantzıs and G. Sabater-Grande, "An Experimental Test of Response Consistency in Contingent Valuation," Ecological Economics, Vol. 47, No. 2-3, 2003, pp.167-182. doi:10.1016/S0921-8009(03)00192-7

[38] E. Sanjurjo, “Aplicación de la Metodología de Valoración Contingente Para Determinar el Valor que Asignan los Habitantes de San Luís Río Colorado a la Existencia de Flujos de Agua en la Zona del Delta del Río Colorado," Dirección de Economía Ambiental, INE-SEMARNAT, Mexico, 2006

[39] M. J. Jimenez-Moreno, "Valoración de Algunos Recursos Naturales, Para Conocer la Disponibilidad de Pago por Servicios Ambientales en el Municipio de Tepetlaoxtoc," Tesis, Universidad Autónoma Chapingo, Chapingo, 2004.

[40] A. Garcia-Angeles, "Valoración Económica de los ServiCios Ambientales de Santa Catarina Ixtepeji, Distrito de
Ixtlán, Oaxaca," Tesis, Universidad Autónoma Chapingo, Chapingo, 2006.

[41] L. M. Orozco-Paredes, "Balance Hidrológico y Valoración Económica de la Producción de agua en la Microcuenca del Río Zahuapan, Tlaxco, Tlax," Tesis, Universidad Autónoma Chapingo, Chapingo, 2006.

[42] R. Monroy-Hernandez, "Valoración Económica del Servicio Ambiental Hidrológico en la Reserva de la Biosfera Barranca de Metztitlán, Hidalgo," Tesis, Universidad Autónoma Chapingo, Chapingo, 2008.

[43] L. B. Chan-Yam, "Valoración Económica del Agua Para Conocer la Disponibilidad de Pago en Comunidades Presentes en ÁPFF Sierra Álamos-Rio Cuchujaqui, Álamos, Sonora," Tesis, Universidad Autónoma Chapingo, Chapingo, 2007.

[44] S. Dietz and W. N. Adger, "Economic Growth, BiodiverSity Loss and Conservation Effort," Journal of Environmental Management, Vol. 68, No. 1, 2003, pp. 23-35. doi:10.1016/S0301-4797(02)00231-1

[45] J. Mills and T. A. Waite, "Economic Prosperity, Biodiversity Conservations, and the Environmental Kuznets Curve," Ecological Economics, Vol. 68, No. 7, 2009, pp. 2087-2095. doi:10.1016/j.ecolecon.2009.01.017 